\section{Distribution of Nutrients in Cut-flower Roses and the Quantities of Biomass and Nutrients Removed during Harvest}

\author{
Yusuf N. Tamimi ${ }^{1}$ and Dennis T. Matsuyama ${ }^{2}$ \\ Department of Agronomy and Soil Science, University of Hawaii at Manoa, \\ Beaumont Agricultural Research Center, 461 West Lanikaula Street, Hilo, \\ HI 96720
}

Kimberly D. Ison-Takata ${ }^{3}$
Watanabe Floral, P.O. Box 1347, Kamuela, HI 96743

Richard T. Nakano ${ }^{4}$

Cooperative Extension Service, University of Hawaii at Manoa, P.O. Box 237, Kamuela, HI 96743

Additional index words. nutrient uptake, fertilization, sustainable production, groundwater, Rosa sp.

Abstract. Pollution of the environment, especially groundwater, may be reduced by proper fertilizer management, based in part on crop removal. The weights and concentrations of nutrients in tissue components of cut-flower roses (Rosa hybrida L.) were determined to assist in developing a fertilizer management system that sustains a high level of production but also is environmentally friendly. Harvested flower stalks of the cv. Royalty were cut to $45-\mathrm{cm}$ length, and sectioned into $15-\mathrm{cm}$ units, from which blossom, leaf, and stem components were separated, weighed, and analyzed for nutrients. The flower represented $\mathbf{2 8 . 5} \%$, leaves $\mathbf{4 6 . 0 \%}$, and stem $25.5 \%$ of the total weight of the stalk. Upper leaves had the highest levels $\left(\mathrm{g} \cdot \mathrm{kg}^{-1}\right)$ of $\mathrm{N}(29.3), \mathrm{Ca}(21.8)$, and $\mathrm{Mg}(3.0)$, and $\left(\mathrm{mg} \cdot \mathrm{kg}^{-1}\right) \mathrm{Fe}(74)$ and $\mathrm{Mn}(71)$. The flower was highest in $\mathrm{K}\left(18.4 \mathrm{~g} \cdot \mathrm{kg}^{-1}\right), \mathrm{P}\left(3.0 \mathrm{~g} \cdot \mathrm{kg}^{-1}\right), \mathrm{Zn}\left(29 \mathrm{mg} \cdot \mathrm{kg}^{-1}\right)$, and B $\left(23 \mathrm{mg} \cdot \mathrm{kg}^{-1}\right)$. Annual removal of nutrients by 45 -cm flower stalks totaled: $256.2,187.5,116.3,30.0,26.0$, and $21.1 \mathrm{~kg} \cdot \mathrm{ha}^{-1}$ of $\mathrm{N}, \mathrm{K}, \mathrm{Ca}, \mathrm{P}, \mathrm{Mg}$, and $\mathrm{S}$, respectively. Micronutrients removed per annum totaled 700, 470, 260, 200, and $190 \mathrm{~g} \cdot \mathrm{ha}^{-1}$ of $\mathrm{Fe}, \mathrm{Mn}, \mathrm{Zn}, \mathrm{Cu}$, and $\mathrm{B}$, respectively. Assuming 50\% recovery of applied $\mathrm{N}$ and $80 \%$ of $\mathrm{K}$, a total annual application of $\mathrm{N}$ at 512 $\mathrm{kg} \cdot \mathrm{ha}^{-1}$ and $\mathrm{K}$ at $234 \mathrm{~kg} \cdot \mathrm{ha}^{-1}$ may replace the amounts removed. However, actual rates of $\mathrm{N}$ and $\mathrm{K}$, as well as other nutrients applied, should be adjusted based on soil and tissue analysis results. Removal of nutrients will be greater if stalks harvested are $>45 \mathrm{~cm}$ in length, which may necessitate additional nutrient application, depending on soil conditions.

Rose harvesting in Hawaii is a year-round activity. The farm-gate value of cut-flower roses for the state of Hawaii in 1993 was nearly $\$ 4$ million U.S. (Statistics of Hawaiian Agriculture, 1994). Intensive production of cut flowers demands high levels of fertilization as well as ample water. Improper fertilization in combination with excessive irrigation may contribute to environmental pollution, especially of groundwater, waste valuable re-

Received for publication 9 Dec. 1997. Accepted for publication 10 Aug. 1998. This research was supported in part by a grant from the Research and Development Dept. of the County of Hawaii and Watanabe Floral of Kamuela, Hawaii. The cost of publishing this paper was defrayed in part by the payment of page charges. Under postal regulations, this paper therefore must be hereby marked advertisement solely to indicate this fact.

${ }^{1}$ Soil Scientist, Emeritus; to whom reprint requests should be addressed.

${ }^{2}$ Research Associate.

${ }^{3}$ Production Manager.

${ }^{4}$ County Extension Agent, Emeritus. sources, and reduce the profit margin. In the past, some growers reportedly applied ductivity depends on the amounts, forms, frequency of application of plant nutrie by a plant at any time are dependent upon its beyond the reach of plant roots, volatilization of certain elements, such as nitrogen, and immobilization of nutrients by soil minerals or by soil microbiological activities must be factored in when a total nutrient budget for sustainable production is formulated.

Most of the data in the literature on mineral content of roses are limited to leaf analyses for diagnostic purposes (Boodley and White, 1969; Carlson, 1966; Oertli, 1966; Owen and Massey, 1953; Post and Fischer, 1951; Sadasivaiah and Holley, 1973; Seely and Davidson, 1939). Carlson and Bergman (1965) reported elemental concentrations of components of cut-flower roses, including blossoms, leaves, and stems, but did not address total nutrient uptake. Bagatto et al. (1991) found significant changes in the concentrations of several nutrients in leaves and stems as a result of stem gall formation. No information is available on the removal of nutrients by cut-flower roses. If we are to seriously protect our environment from pollution, we must develop fertilizer application strategies that allow for optimum crop production without contributing to the pollution of groundwater. An accurate and balanced nutrient budget for roses and other crops based on actual field data is essential to prevent further pollution of our environment. The objectives of this study with cut-flower roses were to determine: 1) the total biomass removed when harvesting stems, 2) the distribution of nutrient elements in them, and 3) the quantity of nutrients that are removed with each harvest in order to formulate a nutrient budget that meets the requirement for optimum production, yet reduces the risk of overapplication.

\section{Materials and Methods}

Cut-flower roses were obtained from Watanabe Floral, located in Lalamilo on the island of Hawaii at an elevation of $900 \mathrm{~m}$. The cultivar Royalty was established in Summer 1990 with cv. Odorata as the rootstock. Planting was in beds $1.2 \mathrm{~m}$ wide with a density of 10 plants $/ \mathrm{m}^{2}$, giving a population of 61,775 plants/ ha with mean annual production of 30 stems/ plant. This figure was used to calculate annual nutrient removal in $\mathrm{kg} \cdot \mathrm{ha}^{-1}$. The soil at this location belongs to the Waimea series (silty clay loam, a Mollic Haplustand of the order Andisol). Analysis of the soil prior to initiation of the study gave: $\mathrm{pH}$ 6.7; organic carbon, $8.23 \% ; \mathrm{P}, 45 \mathrm{mg} \cdot \mathrm{kg}^{-1}$ (modified Truog method), neutral ammonium acetate extractable cat-

Table 1. Fertilizers applied to rose plants by the grower during the time of the study.

\begin{tabular}{lccc}
\hline \hline Fertilizer & Element & \% In fertilizer & $\begin{array}{c}\text { Total applied/year } \\
\left(\mathrm{kg} \mathrm{ha}^{-1}\right)\end{array}$ \\
\hline Calcium nitrate & $\mathrm{N}$ & 15.5 & 448 \\
& $\mathrm{Ca}$ & 22.2 & 642 \\
Ammonium nitrate & $\mathrm{N}$ & 33 & 345 \\
Diammonium phosphate & $\mathrm{N}$ & 21 & 103 \\
& $\mathrm{P}$ & 22.5 & 112 \\
Iron chelate & $\mathrm{Fe}$ & 13 & 11.2 \\
Zinc chelate & $\mathrm{Zn}$ & 13.2 & 5.6 \\
Solubor & $\mathrm{B}$ & 20.5 & 11.2 \\
Potassium-magnesium sulfate & $\mathrm{K}$ & 18.3 & 168 \\
& $\mathrm{Mg}$ & 10.8 & 100 \\
\hline
\end{tabular}

(1)


Table 2. Biomass of components in 45 -cm cutflower $\operatorname{roses}^{2}(n=126)$.

\begin{tabular}{lcccc}
\hline \hline & \multicolumn{2}{c}{ Weight $(\mathrm{g})$} & & Dry weight \\
\cline { 2 - 3 } Tissue & Fresh & Dry & & (\% of total) \\
\hline Flower & 10.47 & $1.88 \mathrm{a}$ & 28.5 \\
Section, 0-15cm & & & \\
$\quad$ Leaves & 1.66 & $0.43 \mathrm{f}$ & 6.5 \\
$\quad$ Stem & 1.64 & $0.32 \mathrm{~g}$ & 4.9 \\
$\quad$ Section, 15-30cm & & & \\
$\quad$ Leaves & 4.39 & $1.24 \mathrm{c}$ & 18.8 \\
$\quad$ Stem & 1.95 & $0.55 \mathrm{e}$ & 8.4 \\
$\quad$ Section, 30-45cm & & & \\
$\quad$ Leaves & 4.82 & $1.36 \mathrm{~b}$ & 20.6 \\
$\quad$ Stem & 2.70 & $0.81 \mathrm{~d}$ & 12.3 \\
$\quad$ Total & 27.61 & 6.59 & 100.0 \\
\hline
\end{tabular}

${ }^{2}$ Mean separation within columns by LSD at $P \leq 0.05$.

ions; $\mathrm{K}, 1738 \mathrm{mg} \cdot \mathrm{kg}^{-1} ; \mathrm{Ca}, 5270 \mathrm{mg} \cdot \mathrm{kg}^{-1}, \mathrm{Mg}$ $770 \mathrm{mg} \cdot \mathrm{kg}^{-1}$. Current fertilization practices (Table 1) were based on Cooperative Extension Service recommendations. All fertilizers were applied through drip irrigation, which was scheduled according to pan evaporation with an average of $253,960 \mathrm{~L} \cdot \mathrm{ha}^{-1}$ being applied weekly.

Cut flowers with stalks $>45 \mathrm{~cm}$ were shipped to our laboratory in Hilo at biweekly intervals starting 8 Apr. and ending 14 June 1993, for a total of six sampling dates (considered as replications in time). Each bundle consisted of 20 stems picked at random, with three bundles per sampling date. Each bundle was considered a subsample within replicates. All bundles were harvested from the same greenhouse, then packed and chilled before shipment. On arrival, stems were measured for length and weighed fresh, trimmed to 45 $\mathrm{cm}$, then rinsed in deionized water and blotted dry. Each stalk was divided into three $15-\mathrm{cm}$ sections and the top section was separated into flower, leaves, and stem, while the bottom two were separated into leaves and stem. Each portion was weighed fresh, then oven dried at $55^{\circ} \mathrm{C}$ to a constant weight. All samples were ground in a stainless steel Wiley mill. Sections of stalks from an individual bundle were composited by section and treated as a composite sample.

Tissue samples were analyzed by the College of Tropical Agriculture and Human Resources Agricultural Diagnostic Service Center at the Univ. of Hawaii at Manoa. Total N was analyzed according to Nelson and Sommers (1972) and Isaac and Johnson (1976). The concentrations of $\mathrm{P}, \mathrm{K}, \mathrm{Ca}, \mathrm{Mg}, \mathrm{Fe}, \mathrm{Mn}$, $\mathrm{Zn}$, and $\mathrm{Cu}$ were determined by inductively coupled plasma emission spectrometry (Isaac and Johnson, 1985); S according to Harlin and Soltanpour (1980), Novozarnsky et al. (1986), and Wall et al. (1980); and B by the azomethine method (Wolf, 1974). Quantitative nutrient uptake by components of the $45-\mathrm{cm}$ sections was calculated. All data were subjected to PROC GLM statistical analysis using SAS (SAS Institute, 1985), and means were separated using least significant difference (LSD), which was based on the Rep (sampling dates) $\times$ Tissue mean square.

Growers in Hawaii may harvest blossoms for leis only, or for cut flowers of various lengths. Therefore, sectioning the stalk and analyzing the components allows the grower to calculate nutrient removal in accordance with the harvesting mode.

\section{Results}

Biomass production. Cut-flower roses ranged in length from 53.3 to $80.0 \mathrm{~cm}$ with a mean length of $64.0 \mathrm{~cm}$. Stem fresh weight (FW) ranged from 21.0 to $58.0 \mathrm{~g}$, with a mean of $37.2 \mathrm{~g} / \mathrm{stalk}$ prior to trimming. When trimmed to $45 \mathrm{~cm}$, the mean FW was $27.6 \mathrm{~g}$ and the dry weight (DW) was $6.6 \mathrm{~g}$ (Table 2). Flowers constituted $28.5 \%$, leaves $46.0 \%$, and stems $25.5 \%$ of the total DW.

Elemental concentrations of components. A. Macronutrients. Flowers, when contrasted with leaf and stem components, had the highest concentrations of $\mathrm{P}$ and $\mathrm{K}$, intermediate levels of $\mathrm{N}, \mathrm{Mg}$, and $\mathrm{S}$, and the lowest levels of $\mathrm{Ca}$ (Table 3). Leaves were higher than other tissues in $\mathrm{N}, \mathrm{Ca}, \mathrm{Mg}$, and $\mathrm{S}$, while stem tissue was the lowest in nearly all of the macronutrients. Leaf concentrations of $\mathrm{N}, \mathrm{Ca}$, and $\mathrm{Mg}$ decreased with increasing age and $\mathrm{K}$ was higher in older leaves, but levels of $\mathrm{P}$ and $\mathrm{S}$ did not vary with age. In the stem, older tissue contained lower concentrations of $\mathrm{N}, \mathrm{K}$, and $\mathrm{Ca}$, while age had little effect on levels of $\mathrm{P}$ and $\mathrm{S}$; however, $\mathrm{Mg}$ was slightly higher in older tissue (Table 3). A statistically significant effect of sampling date $(P \leq 0.01)$ was found for $\mathrm{P}, \mathrm{K}, \mathrm{Ca}, \mathrm{Mg}$, and $\mathrm{S}$, but no meaningful pattern over time was apparent for any tissue.
The ranges recorded for each element are reported in Table 3 . The sampling date $\times$ tissue interaction term was significant only for $\mathrm{N}$. This interaction was not due to any substantial change in ranking of the tissues, but rather to the magnitude of the differences between tissues varying somewhat over time.

B. Micronutrients. Tissue concentrations of $\mathrm{Zn}$ and $\mathrm{B}$ were higher in flowers than in leaves or stems (Table 3). Concentrations of $\mathrm{Fe}$ and $\mathrm{Mn}$ were higher in leaves than in flowers or stems, and concentrations of $\mathrm{Cu}$ were highest in stems. Youngest leaves contained slightly higher concentrations of Fe and $\mathrm{Mn}$ than did older leaves, while age had little effect on concentrations of $\mathrm{Zn}, \mathrm{Cu}$, or B. Older stem tissue had higher concentrations of $\mathrm{Zn}$ and $\mathrm{Cu}$, while $\mathrm{Mn}$ content was not influenced by age; $\mathrm{B}$ was slightly higher in younger stem tissue (Table 3 ). A statistically significant effect of sampling date $(P \leq 0.01)$ was found for $\mathrm{Cu}$ and $\mathrm{Zn}$, but no meaningful pattern over time was apparent. The sampling date $\times$ tissue interaction was significant for $\mathrm{Fe}, \mathrm{Zn}$, and $\mathrm{Cu}$. This interaction may be due to the magnitude of the differences between tissues varying over time, rather than any substantial change in ranking of the tissues. The overlap of statistical differences in the means reflects changes in ranking of the tissues over time.

Uptake of nutrients. A. Macronutrients. The amounts of $\mathrm{N}, \mathrm{P}, \mathrm{K}$, and $\mathrm{Mg}$ removed by cut-flower roses were highest in the flowers, intermediate in the lowest leaves, and least in the stems (Table 4). Calcium was highest in the middle leaves, with less in the lowest and upper leaves, followed by the flowers, and least in the stem sections. The lowest leaves removed the largest quantities of $\mathrm{S}$, followed by the flower, and then the middle and upper leaves. As with other nutrients, the amount of $\mathrm{S}$ was lowest in the stem portions of the stalk (Table 4).

B. Micronutrients. The amounts of micronutrients removed by cut-flower roses were extremely small in comparison with the macronutrients (Table 4). Among all tissues tested, the flower removed the highest amounts of $\mathrm{Fe}$, $\mathrm{Zn}$, and $\mathrm{B}$, but $\mathrm{Cu}$ was removed equally by the flowers and the bottom leaves. Among leaves, basal ones removed the highest amounts of most micronutrients, followed by the middle and then the apical ones, except for Mn where

Table 3. Levels of nutrients in tissue components of cut-flower $\operatorname{roses}^{\mathrm{z}}(\mathrm{n}=126)$.

\begin{tabular}{|c|c|c|c|c|c|c|c|c|c|c|c|}
\hline \multirow{2}{*}{ Tissue } & \multicolumn{11}{|c|}{ Element } \\
\hline & $\mathrm{N}$ & $\mathrm{P}$ & $\mathrm{K}$ & $\mathrm{Ca}$ & $\mathrm{Mg}$ & $\mathrm{S}$ & $\mathrm{Fe}$ & $\mathrm{Mn}$ & $\mathrm{Zn}$ & $\mathrm{Cu}$ & B \\
\hline Flower & $20.9 \mathrm{c}$ & $3.0 \mathrm{a}$ & $18.4 \mathrm{a}$ & $3.8 \mathrm{e}$ & $2.2 \mathrm{~d}$ & $1.6 \mathrm{~b}$ & $63 \mathrm{ab}$ & $29 \mathrm{c}$ & $29 \mathrm{a}$ & $13 \mathrm{c}$ & $23 \mathrm{a}$ \\
\hline Leaf & $29.3 \mathrm{a}$ & $2.3 \mathrm{~b}$ & $14.3 \mathrm{~d}$ & $21.8 \mathrm{a}$ & $3.0 \mathrm{a}$ & $2.4 \mathrm{a}$ & $74 \mathrm{a}$ & $71 \mathrm{a}$ & $22 \mathrm{~b}$ & $16 \mathrm{bc}$ & $13 \mathrm{c}$ \\
\hline Stem & $10.5 \mathrm{~d}$ & $1.9 \mathrm{~d}$ & $15.3 \mathrm{c}$ & $7.2 \mathrm{~d}$ & $0.8 \mathrm{f}$ & $0.8 \mathrm{c}$ & $42 \mathrm{~d}$ & $17 \mathrm{~d}$ & $18 \mathrm{c}$ & $18 \mathrm{~b}$ & $18 \mathrm{~b}$ \\
\hline \multicolumn{12}{|c|}{ Stem section, $15-30 \mathrm{~cm}$} \\
\hline \multicolumn{12}{|c|}{ Stem section, $30-45 \mathrm{~cm}$} \\
\hline Leaf & $27.1 \mathrm{~b}$ & $2.4 \mathrm{~b}$ & $17.0 \mathrm{~b}$ & $14.2 \mathrm{c}$ & $2.4 \mathrm{c}$ & $2.4 \mathrm{a}$ & $57 \mathrm{~b}$ & $54 \mathrm{~b}$ & $19 \mathrm{c}$ & $17 \mathrm{bc}$ & $15 \mathrm{bc}$ \\
\hline Stem & $8.4 \mathrm{e}$ & $2.0 \mathrm{~d}$ & $9.2 \mathrm{e}$ & $3.3 \mathrm{f}$ & $1.4 \mathrm{e}$ & $0.6 \mathrm{~d}$ & $44 \mathrm{~cd}$ & $18 \mathrm{~d}$ & $26 \mathrm{a}$ & $27 \mathrm{a}$ & $13 \mathrm{c}$ \\
\hline
\end{tabular}

${ }^{2}$ Mean separation within columns by LSD at $P \leq 0.05$. 


\begin{tabular}{|c|c|c|c|c|c|c|c|c|c|c|c|}
\hline \multirow[b]{3}{*}{ Tissue } & \multicolumn{11}{|c|}{ Element } \\
\hline & $\mathrm{N}$ & $\mathrm{P}$ & $\mathrm{K}$ & $\mathrm{Ca}$ & $\mathrm{Mg}$ & $\mathrm{S}$ & $\mathrm{Fe}$ & $\mathrm{Mn}$ & $\mathrm{Zn}$ & $\mathrm{Cu}$ & $\mathrm{B}$ \\
\hline & \multicolumn{6}{|c|}{$\mathrm{kg} \cdot \mathrm{ha}^{-1}$} & \multicolumn{5}{|c|}{$g \cdot h a^{-1}$} \\
\hline Flower & $72.9 \mathrm{a}$ & $10.4 \mathrm{a}$ & $64.1 \mathrm{a}$ & $13.2 \mathrm{c}$ & $7.7 \mathrm{a}$ & $5.6 \mathrm{~b}$ & $220 \mathrm{a}$ & $100 \mathrm{~b}$ & $100 \mathrm{a}$ & $40 \mathrm{a}$ & $80 \mathrm{a}$ \\
\hline \multicolumn{12}{|c|}{ Stem section, $0-15 \mathrm{~cm}$} \\
\hline Leaf & $23.1 \mathrm{~d}$ & $1.8 \mathrm{e}$ & $11.3 \mathrm{de}$ & $17.2 \mathrm{~b}$ & $2.4 \mathrm{c}$ & $1.9 \mathrm{c}$ & $60 \mathrm{c}$ & $60 \mathrm{c}$ & $20 \mathrm{c}$ & $10 \mathrm{c}$ & $10 \mathrm{c}$ \\
\hline Stem & $6.2 \mathrm{f}$ & $1.1 \mathrm{f}$ & $9.1 \mathrm{e}$ & $4.3 \mathrm{~d}$ & $0.5 \mathrm{e}$ & $0.5 \mathrm{~d}$ & $20 \mathrm{~d}$ & $10 \mathrm{e}$ & $10 \mathrm{c}$ & $10 \mathrm{c}$ & $10 \mathrm{c}$ \\
\hline \multicolumn{12}{|c|}{ Stem section, $15-30 \mathrm{~cm}$} \\
\hline Leaf & $63.2 \mathrm{c}$ & $5.3 \mathrm{c}$ & $36.9 \mathrm{c}$ & $36.6 \mathrm{a}$ & $6.0 \mathrm{~b}$ & $5.5 \mathrm{~b}$ & $120 \mathrm{~b}$ & $130 \mathrm{a}$ & $40 \mathrm{~b}$ & $30 \mathrm{~b}$ & $30 \mathrm{~b}$ \\
\hline Stem & $10.3 \mathrm{ef}$ & $2.2 \mathrm{e}$ & $9.5 \mathrm{e}$ & $4.3 \mathrm{~d}$ & $1.3 \mathrm{~d}$ & $0.7 \mathrm{~d}$ & $60 \mathrm{c}$ & $20 \mathrm{de}$ & $20 \mathrm{c}$ & $30 \mathrm{~b}$ & $10 \mathrm{c}$ \\
\hline \multicolumn{12}{|c|}{ Stem section, $30-45 \mathrm{~cm}$} \\
\hline Leaf & $68.1 \mathrm{~b}$ & $6.0 \mathrm{~b}$ & $42.7 \mathrm{~b}$ & $35.7 \mathrm{a}$ & $6.0 \mathrm{~b}$ & $6.0 \mathrm{a}$ & $150 \mathrm{~b}$ & $130 \mathrm{a}$ & $40 \mathrm{~b}$ & $40 \mathrm{a}$ & $30 \mathrm{~b}$ \\
\hline Stem & $12.6 \mathrm{e}$ & $3.1 \mathrm{~d}$ & $13.9 \mathrm{~d}$ & $5.0 \mathrm{~d}$ & $22.1 \mathrm{c}$ & $0.9 \mathrm{~d}$ & $70 \mathrm{c}$ & $20 \mathrm{de}$ & $30 \mathrm{~b}$ & $40 \mathrm{a}$ & $20 \mathrm{c}$ \\
\hline Total & 256.2 & 30.0 & 187.5 & 116.3 & 26.0 & 21.1 & 700 & 470 & 260 & 200 & 190 \\
\hline
\end{tabular}

${ }^{\mathrm{z}}$ Mean separation within columns by LSD at $P \leq 0.05$.

quantities for the bottom and middle were equal. Similarly, the basal part of the stem removed the most micronutrients, followed by the middle, then the upper section.

Nutrient removal by the three major tissue components was calculated by totaling the amounts present in each tissue. The leaves had the highest proportion of all macro and micronutrients (the range was $38.1 \%$ for $\mathrm{Zn}$ to $77.0 \%$ for $\mathrm{Ca}$ ), the flower ranked second, except for calcium and copper (11.4\% for Ca to $38.1 \%$ for B), and the stem contained the least amount of most nutrients $(10.1 \%$ for $\mathrm{S}$ to $36.9 \%$ for $\mathrm{Cu}$ ).

\section{Discussion}

The data presented here make it possible to calculate the amounts of the various nutrients removed by the harvested rose biomass. A nutrient replacement program can be formulated in order to sustain production and avoid overapplication of fertilizers. The harvested biomass had a mean additional length of $19 \mathrm{~cm}$ with a FW of $9 \mathrm{~g}$, which is $35 \%$ more than the stalk that was trimmed to $45 \mathrm{~cm}$. For a harvested length of $45 \mathrm{~cm}, 256 \mathrm{~kg} \cdot \mathrm{ha}^{-1} \mathrm{~N}$ and 187 $\mathrm{kg} \cdot \mathrm{ha}^{-1} \mathrm{~K}$ were removed annually (Table 4 ). These are by far the most heavily utilized nutrients. Annual removal $\left(\mathrm{kg} \cdot \mathrm{ha}^{-1}\right)$ of the other macronutrients was as follows: $\mathrm{Ca}, 116 ; \mathrm{P}, 30$ $\mathrm{Mg}, 26$; and $\mathrm{S}, 21$. The amounts of micronutrients removed per annum were very small, ranging from $700 \mathrm{~g} \cdot \mathrm{ha}^{-1}$ for Fe to $190 \mathrm{~g} \cdot \mathrm{ha}^{-1}$ for B (Table 4). All these amounts may be increased by $\approx 35 \%$ to compensate for the discarded biomass.

Nitrogen fertilizer recovery by plants is influenced by many factors. These include: the nature of the plant and its root system; the form, amount, and frequency of application of nitrogen; soil physical and chemical properties, including soil organic matter, and cation and anion exchange capacities; biological, chemical, and physical immobilization; rate of water percolation; amount of irrigation or rain frequency and intensity; and volatilization.

Existing publications on rose nutrition con- tain no data on the efficiency of utilization of nutrients by the plant. Using the data collected in this study, we attempted to calculate the efficiency of utilization of nitrogen fertilizer. An annual $\mathrm{N}$ application of $896 \mathrm{~kg} \cdot \mathrm{ha}^{-1}$ and removal by biomass of $346 \mathrm{~kg} \cdot \mathrm{ha}^{-1}$ give an utilization efficiency of $39 \%$. In contrast, recovery of fertilizer $\mathrm{N}$ by maize in the aboveground portion of the plant, with optimum yield, over 13 consecutive crops was $50 \%$ to $60 \%$ (unpublished data by Y.N. Tamimi and D.T. Matsuyama). Similar data reported by Hill et al. (1983) showed a recovery of $57 \%$ of applied N. If we were to consider $50 \%$ to $60 \%$ recovery by roses, then an annual rate of $\mathrm{N}$ at 577 to $692 \mathrm{~kg} \cdot \mathrm{ha}^{-1}$ would be required. The timing and quantities of $\mathrm{N}$ fertilizer to be applied in split increments can be adjusted by taking into consideration tissue analysis, seasonality of demand for flowers, and cultural practices.

In a similar manner, annual $\mathrm{K}$ removal by the harvested biomass was calculated at 253 $\mathrm{kg} \cdot \mathrm{ha}^{-1}$. Potassium can be applied as soil analysis dictates. If a $75 \%$ to $80 \%$ recovery is assumed, an annual rate of 316 to $337 \mathrm{~kg} \cdot \mathrm{ha}^{-1}$ will replace what is removed. Removal rates of other nutrients may be determined by considering the nutrient uptake reported in Table 4. We suggest that periodic soil and tissue tests be used to determine the need for application of all nutrients.

\section{Literature Cited}

Bagatto, G., T.J.Zimijowskyj, and J.D. Shorthouse. 1991. Galls induced by Diplolepis spinosa influence distribution of mineral nutrients in the shrub rose. HortScience 26:1283-1284.

Boodley, J.W. and J.W. White. 1969. Fertilization, p. 78-92. In: J.W. Mastalerz and R.W. Langhans (eds.). Roses. Pennsylvania Flower Growers, New York State Flower Growers Assoc., and Roses, Inc.

Carlson, W.H. 1966. Foliar analysis, a new tool. Roses Inc. Bul. Dec. 1966, p. 25-28.

Carlson, W.H. and E.L. Bergman. 1965. Tissue analyses of greenhouse roses (Rosa hybrida) and correlation with flower yield. Proc. Amer. Soc. Hort. Sci. 88:671-677.
Harlin, J. L. and P.N. Soltanpour. 1980. A nitric acid plant tissue digest method for use with inductively coupled plasma spectrometry. Commun. Soil Sci. Plant Analysis 11:969-980.

Hawaii Dept. of Agriculture, Marketing Division, and U.S. Dept. of Agriculture. 1994. Statistics of Hawaiian agriculture. Natl. Agr. Stat. Serv., Honolulu.

Hills, F.J., F.E. Broadbent, and O.A. Lorenz. 1983. Fertilizer nitrogen utilization by corn, tomatoes and sugarbeets. Agron. J. 75:423-426.

Isaac, R.A. and W.C. Johnson. 1976. Determination of total nitrogen in plant tissue, using a block digestor. J. Assoc. Offic. Anal. Chemists 59:98100

Isaac, R.A. and W.C. Johnson. 1985. Elemental analysis of plant tissue by plasma emission spectroscopy: Collaborative study. J. Assoc. Offic. Anal. Chemists 68:499-505.

Nelson, D.W. and L.E. Sommers. 1972. Determination of total nitrogen in plant material. Agron. J. 65:109-112.

Novozarnsky, I., R. Van Eck, J.J. Van der Lee, V.J.G. Houba, and E. Temminghoft. 1986. Determination of total sulfur and extractable sulfate in plant materials by inductively coupled plasma atomic emission spectroscopy. Commun. Soil Sci. Plant Anal. 17:1147-1157.

Oertli, J.J. 1966. Nutrient deficiencies in rose plants. Florist Rev. 138:3578-3585.

Owen, O. and D.M. Massey. 1953. Lime-induced manganese deficiency in glasshouse roses. Plant Soil 5:81-86.

Post, K. and C.W. Fischer, Jr. 1951. The potassiumcalcium nutrition of greenhouse roses. Proc. Amer. Soc. Hort. Sci. 57:361-368.

Sadasivaiah, S.P. and W.D. Holley. 1973. Ion balance in nutrition of greenhouse roses. Roses Inc. Bul. Suppl. Nov. 1973.

SAS Institute. 1985. SAS procedures guide for personal computers, ver. 6 ed. SAS Inst., Cary, N.C.

Seeley, J.G. and O.W. Davidson. 1939. Interrelationships of calcium and phosphorus concentrations on the growth of roses. Proc. Amer. Soc. Hort. Sci. 37:967-971.

Wall, L.L., C.W. Gehrke, and J. Suzuki. 1980. An automated turbidimetric method for total sulfur in plant tissue and sulfate sulfur in soils. Commun. Soil Sci. Plant Anal. 11:1087-1103.

Wolf, B. 1974. Improvements in the azo-methine-H method for the determination of boron. Commun. Soil Sci. Plant Anal. 5:39-44. 